\title{
Indigenous multiresistant bacteria of Cupriavidus pauculus IrC4 isolated from Indonesia as a heavy metal bioremediation agent
}

\author{
WAHYU IRAWATI ${ }^{1, \bullet}$, STEVANUS ERICK WINOTO ${ }^{2}$, LUCIA KUSUMAWATI ${ }^{3}$, REINHARD PINONTOAN ${ }^{2}$ \\ ${ }^{1}$ Department of Biology Education, Faculty of Education, Universitas Pelita Harapan. Jl. M.H. Thamrin Boulevard 1100, Lippo Karawaci, Tangerang \\ 15811, Banten, Indonesia, Tel./fax.: +62-21-5460910, "email: w.irawati3@ gmail.com \\ ${ }^{2}$ Department of Biology, Faculty of Science and Technology, Universitas Pelita Harapan. Jl. M.H. Thamrin Boulevard 1100, Lippo Karawaci, Tangerang \\ 15811, Banten, Indonesia \\ ${ }^{3}$ Department of Food Technology, Faculty of Life Sciences, International University Liaison Indonesia. The Breeze, BSD City, Tangerang 15345, \\ Banten, Indonesia
}

Manuscript received: 12 March 2021. Revision accepted: 25 May 2021.

\begin{abstract}
Irawati W, Winoto SE, Kusumawati L, Pinontoan R. 2021. Indigenous multiresistant bacteria of Cupriavidus pauculus IrC4 isolated from Indonesia as a heavy metal bioremediation agent. Biodiversitas 22: 3349-3355. Heavy metal pollution is a serious environmental problem because it endangers humans, animals, and plants. Bioremediation of heavy metals using bacteria is an effective method to remove heavy metals. Cupriavidus pauculus $\mathrm{IrC} 4$ is an indigenous multi-resistant bacteria isolated from Indonesia. This study aims to determine the growth of this strain in a medium containing cadmium, mercury, lead, copper, and its ability to accumulate heavy metal. Bacterial resistance was observed by cultivating bacteria on a Luria Bertani medium containing various concentrations of heavy metals. Heavy metal accumulation was measured using atomic absorption spectrophotometer. The study showed that this strain could grow in a solid medium containing $5 \mathrm{mM}$ cadmium, $13 \mathrm{mM}$ lead, and $4 \mathrm{mM}$ mercury, also in $0.5 \mathrm{mM}$ of the heavy metal mixture. A high concentration of heavy metals resulted in lag phase elongation and logarithmic growth phase inhibition. C. pauculus IrC4 could accumulate copper, lead, and cadmium and lead up to $371.42 \mathrm{mg}, 254.4 \mathrm{mg}, 5.8 \mathrm{mg}$ heavy metals per gram of dry weight of cells, respectively. In conclusion, this strain is a promising bacterium for use as a heavy metal bioremediation agent.
\end{abstract}

Keywords: Accumulation, Cupriavidus pauculus $\mathrm{IrC4}$, growth, heavy metals, resistant

Abbreviations: $\mathrm{CuSO}_{4}$ : Copper sulfate, EPS: Exopolysaccharides, MIC: Minimum Inhibitory Concentration

\section{INTRODUCTION}

Increasing industrial activities will indirectly escalate the amount of waste in the environment. Heavy metals are one of the most common pollutants in waste that threaten human life because their presence in the environment cannot be either degraded or easily absorbed by the body (Das et al. 2016). Contamination of copper, zinc, mercury, lead, cadmium, and chromium in the environment is categorized as heavy metal pollution because of their toxicity and abundance in the environment (WHO 2010). This heavy metal is inevitably used in industrial activities and must be taken seriously so as not to endanger the environment and health (Smrithi and Usha 2012).

Bioremediation using bacteria is an effective and economical method to overcome heavy metal pollution by utilizing the intrinsic properties of bacteria such as their ability to bioaccumulate heavy metals (Saranraj and Stella 2012). Bioremediation is an activity involving bacteria to convert heavy metals from toxic to less toxic through a process of degradation, immobilization, detoxification, and accumulation. Bacteria grow easily in all environmental conditions, are widely distributed in nature, and have metabolic activities that can overcome environmental pollution. Some bacteria have a particular metabolism to utilize heavy metals as sources of energy for their growth
(Abatenh et al. 2017).

Several previous studies have shown that indigenous bacteria isolated from polluted environments have good effectiveness for heavy metal bioremediation because these bacteria have adapted to the environments. Bacteria isolated from the environment contaminated with certain heavy metals have a resistance mechanism against these heavy metals. Industrial waste usually contains not only one type but also several heavy metals. Therefore, the bioremediation process will be more efficient when using indigenous bacteria with multi-resistance to heavy metal. Several studies showed that indigenous bacteria isolated from the polluted environment have multi-resistance to heavy metals. Bacillus spp, Pseudomonas spp, Serratia marcescens, Klebsiella pneumonia, Micrococcus spp, and E. coli have resistance to lead and chromium (Pradeepa and Kavitha 2020). Indigenous heavy metals resistant bacteria isolated from discharged effluent showed multiple resistance to $\mathrm{Pb}, \mathrm{Cd}, \mathrm{As}$, and $\mathrm{Ni}$ (Mutiat et al. 2019). Meanwhile, Klebsiella variicola isolated from industrial effluents showed multiple resistance to cobalt and nickel (Afzal et al. 2017).

Cupriavidus metallidurans $\mathrm{CH} 34$, isolated from metallurgical sediments in Belgium, is the most wellknown and studied strain to represent a model of bacteria resistant to heavy metals (Klonowska et al. 2012). The 
ability of some Cupriavidus species to grow in the presence of heavy metals has been reported in several previous studies. C. metallidurans $\mathrm{CH} 34 \mathrm{~T}$ can grow in the presence of copper, chromium, mercury, nickel, silver, cadmium, cobalt, lead, zinc, and arsenic (Santos et al. 2014). Cupriavidus alkaliphilus grow effectively in the presence of arsenic, copper, and zinc. Cupriavidus necator can remove cadmium, zinc, and copper from contaminated soil (Vicentin et al. 2018). Inoculation of this strain increases the ability of Helianthus annuus to deal with heavy metal toxicity when applied as a phytoremediation agent in polluted environments (Santos et al. 2014). Cupriavidus gilardii CR33 has multiple metal resistance to cadmium, zinc, copper, and argentum (Vicentin et al. 2018). Cupriavidus taiwanensis strains show a wide range of tolerances to $\mathrm{Ni}, \mathrm{Zn}$, and $\mathrm{Cr}$ indicating their adaptation to the specific environment in New Caledonia (Klonowska et al. 2012).

Some of these studies showed the diverse characteristics of different species of Cupriavidus species in terms of their multi-resistance to heavy metals. Characteristics determination of new species of Cupriavidus isolated from a polluted environment is important for heavy metal bioremediation. Cupriavidus pauculus $\mathrm{IrC} 4$ is an indigenous bacterium isolated from industrial waste in Indonesia that has multi-resistance to copper, lead, mercury, cadmium, and the mixture of those heavy metals (Irawati et al. 2015). This study aims to observe the growth of $C$. pauculus $\mathrm{IrC} 4$ in a medium containing cadmium, mercury, lead, and copper-based and morphological colony and to determine the ability of bacteria to accumulate heavy metals.

\section{MATERIALS AND METHODS}

\section{Bacterial strain and growth medium}

Cupriavidus pauculus $\mathrm{IrC} 4$ is heavy metals resistant bacteria isolated from activated sludge in an industrial wastewater treatment plant in Rungkut-Surabaya with the accession number of JX398287 (Irawati et al. 2015). Bacteria were grown on Luria Bertani enriched medium with the heavy metal addition after the medium was sterilized. The concentrations of heavy metal used in this study were based on the value of the minimum inhibitory concentration of each heavy metal on the previous research,i.e., $5 \mathrm{mM}-11 \mathrm{mM} \mathrm{CuSO}_{4}, 0.5 \mathrm{mM}-5 \mathrm{mM}$ $\mathrm{Cd}\left(\mathrm{NO}_{3}\right)_{2}, 1 \mathrm{mM}-4 \mathrm{mM} \mathrm{HgCl} 2,7 \mathrm{mM}-13 \mathrm{mM} \mathrm{Pb}\left(\mathrm{NO}_{3}\right)_{2}$, and $0.5 \mathrm{mM}$ the mixture of $\mathrm{CuSO}_{4}, \mathrm{~Pb}\left(\mathrm{NO}_{3}\right)_{2}, \mathrm{Cd}\left(\mathrm{NO}_{3}\right)_{2}$. (Irawati et al. 2015).

\section{Bacterial growth and heavy metal resistance}

Bacterial resistance was measured by cultivating bacteria on a broth medium containing various concentrations of cadmium, mercury, lead, copper, and without heavy metals. Bacteria were cultivated in the culture medium and incubated at $37^{\circ} \mathrm{C}$ in a shaking incubator at $200 \mathrm{rpm}$. Bacterial growth curves were observed to determine the effect of heavy metal types and concentrations using a spectrophotometer at a wavelength of $600 \mathrm{~nm}$. The effect of heavy metal addition on bacterial growth and colony changes was observed by streaking the bacteria onto a solid medium containing various concentrations of heavy metals.

\section{Heavy metal accumulation}

Measurement of the ability of heavy metals accumulation was performed using atomic absorption spectrophotometer (AAS). Bacteria were grown in a liquid medium with the addition of heavy metals in the exponential phase and then the biomass was harvested by centrifugation at $4500 \mathrm{rpm}$ for 15 minutes. Bacterial biomass was dried in the oven at $70^{\circ} \mathrm{C}$ until it reaches constant weight. Then, biomass was digested with $\mathrm{HNO}_{3}$ and heating it at $200^{\circ} \mathrm{C}$. Heavy metal concentrations were measured using an atomic absorption spectrophotometer (Cha and Cooksey 1991).

\section{RESULTS AND DISCUSSION}

\section{Bacterial growth}

The results showed that the presence of heavy metals in the medium affected the colony morphology of $C$. pauculus IrC4. The colony morphology of $C$. pauculus $\mathrm{IrC} 4$ on LB without copper was complete, smooth, shiny, and convex (Figure 1A). The addition of high concentrations of copper, lead, and cadmium caused colony changes to become slimmer as an early indication of the formation of exopolysaccharides (EPS). Further research should be carried out to confirm the presence of EPS visualized by a scanning electron microscope. The increasing concentration of heavy metals in the media resulted in the fewer colony that grew on the agar medium. A similar result was reported by Chien et al. (2013) that Pseudomonas sp. EJ01 can tolerate the addition of $2 \mathrm{mM}$ cadmium by forming a biofilm. Biofilms are formed due to the production of exopolysaccharides which play a role in bacterial resistance.

According to Wuertz et al. (1997), the ability of bacteria to survive in a polluted environment is determined by intrinsic and extrinsic properties including biochemical, physiological, structural, and genetic properties observed from changes in cell morphology and modification of heavy metal speciation. Heavy metal-resistant bacteria can perform other resistance mechanisms, among others, by secretion of exopolysaccharide (EPS). This exopolysaccharide binds copper outside the cell as a form of passive resistance mechanism to protect cells against copper toxicity (Arashiro 2018) and protect bacteria effectively against heavy metal toxicity (Gonzalez et al. 2010). EPS plays a role in both binding copper ions by electrostatic interactions and trapping them outside the cell.

Irawati et al. (2020) reported that the addition of $5 \mathrm{mM}$ $\mathrm{CuSO}_{4}$ caused changes in the edges of the colony of $C$. pauculus $\mathrm{IrC} 4$ to become undulate. The change in the edge of the bacterial colony to undulate might be a manifestation of structural membrane damage because of copper toxicity. Several previous studies showed that undulate-shaped colonies are thought to be a manifestation of membrane 
damage due to heavy metal toxicity (Umamaheshwari et al. 2015; Salam et al. 2019; Wang et al. 2013). According to Chatterjee et al. (2012), heavy metal toxicity affects cell morphology. Monsieurs et al. (2012) reported that excessive concentrations of essential metals such as copper or the presence of toxic non-essential metals such as lead, cadmium, mercury in bacteria could result in structural damage to DNA, cell membranes, and protein denaturation. Rojas et al. (2011) reported that the outer membrane of $C$. metallidurans MR33 was damaged and fuzzy when grown on a mercury-containing medium. On the other hand, Afzal et al. (2017) showed that Klebsiella variicola was damage to the outer membrane resulting in changes in cell morphology when faced with heavy metals nickel and cobalt.

Irawati et al. (2012) showed that the addition of $5 \mathrm{mM}$ $\mathrm{CuSO}_{4}$ caused changes in the colony color to green. Further studies showed that green colony in $C$. pauculus $\mathrm{IrC} 4$ was a manifestation of copper bioaccumulation by CopA protein in the outer membrane (Irawati 2020). These results were supported by Diep et al. (2018) which reported that copper in the inside cells was sequestered by proteins and peptide ligands (Diep et al. 2018). Silva et al. (2018) described that C. metallidurans strains $\mathrm{CH} 34$ and MSR33 had outer membranes and periplasm which were rich in CopA sulfur proteins which play a role in oxidizing and reducing heavy metals. Irawati et al. (2016) succeeded in isolating the gene encoding the CopA protein in copper-resistant bacteria, Acinetobacter sp. IrC1, which was involved in copper binding and caused the colony color to turn green. Several studies also reported that Pseudomonas syringe, Burkholderia sp, Alcaligenes sp, Methylobacterium sp, and Acinetobacter sp performed a resistance mechanism by accumulating copper in the outer membrane and periplasm causing the colony color to turn blue or green (Cha and Cooksey 1991; Kunito et al. 1997). A similar resistance mechanism was also observed in $C$. gilardii through copper bioaccumulation and biosorption (Mazalan et al. 2020).

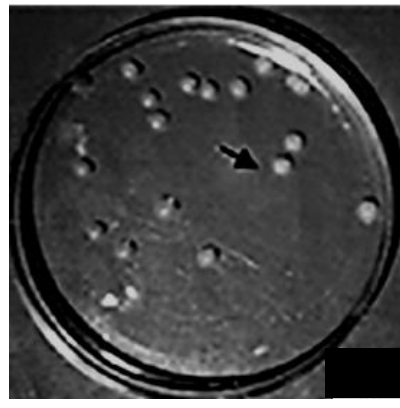

A

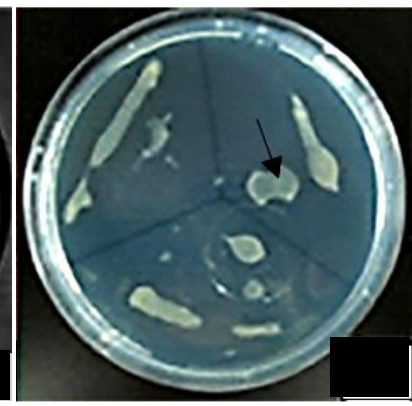

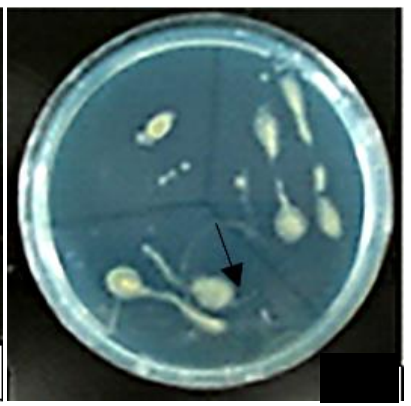

C

Figure 1. The morphological colonies of Cupriavidus pauculus $\mathrm{IrC} 4$ in medium containing various concentrations of copper. A. without $\mathrm{CuSO}_{4}$, B. $10 \mathrm{mM} \mathrm{CuSO}_{4}$, C. $11 \mathrm{mM} \mathrm{CuSO}_{4}$. Arrows show the appearance of slime in the colony

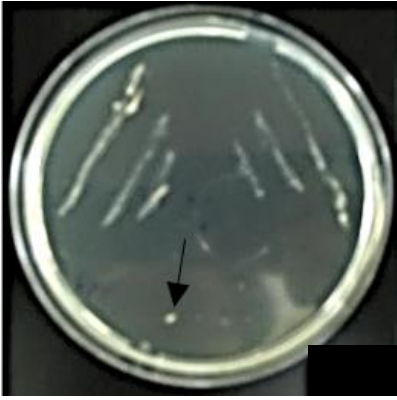

A

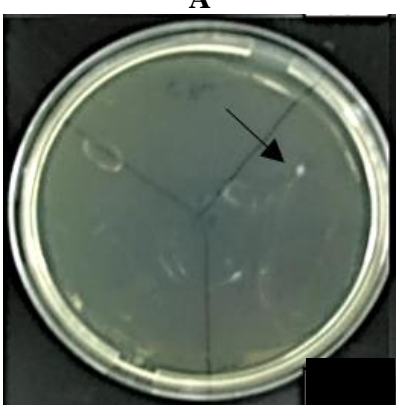

D

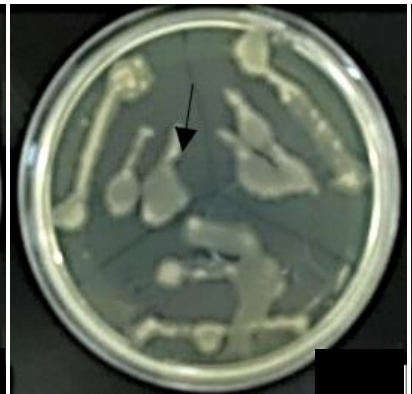

B

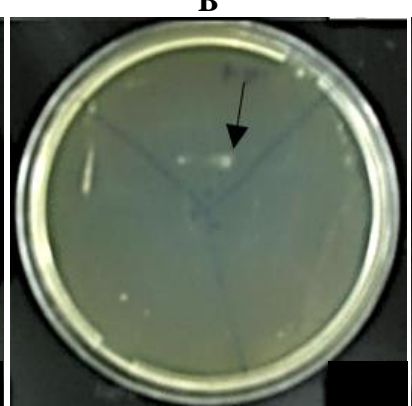

$\mathbf{E}$

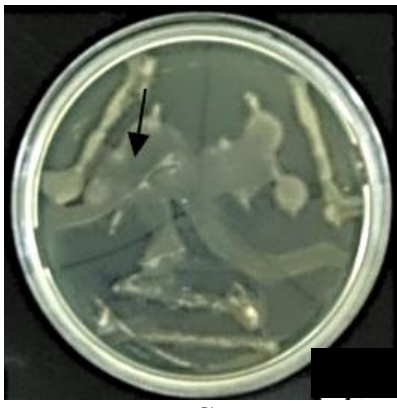

C

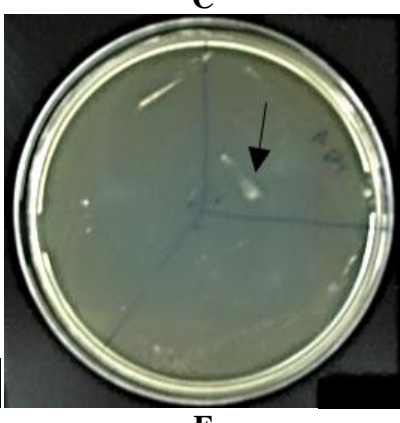

$\mathbf{F}$

Figure 2. The morphological colonies of Cupriavidus pauculus $\mathrm{IrC} 4$ in medium containing various concentrations of mercury. A. $1 \mathrm{mM} \mathrm{Hg}$; B. $1.5 \mathrm{mM} \mathrm{Hg}$; C. $2 \mathrm{mM} \mathrm{Hg}$; D. $2.5 \mathrm{mM} \mathrm{Hg}$; E. $3 \mathrm{mM} \mathrm{Hg}$ and F. $4 \mathrm{mM} \mathrm{Hg}$. Arrows show the appearance of slime in the colony 


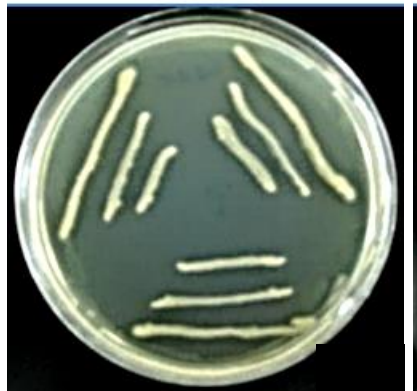

$\mathbf{A}$

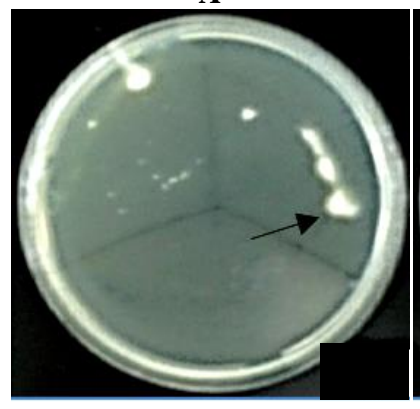

D

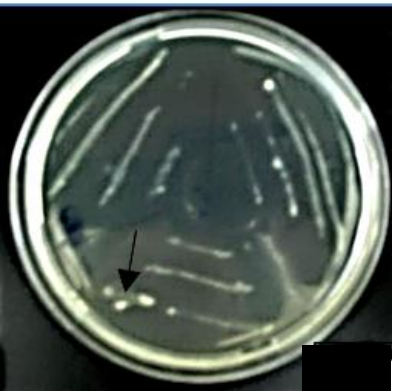

B

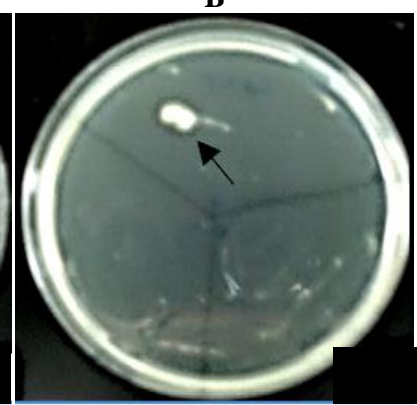

$\mathbf{E}$

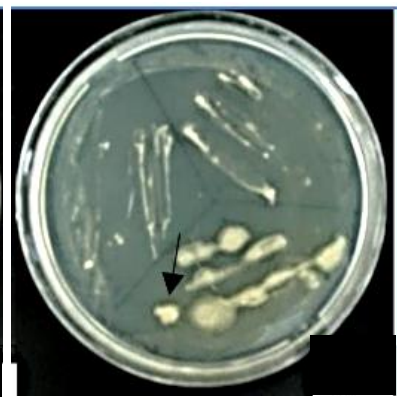

C

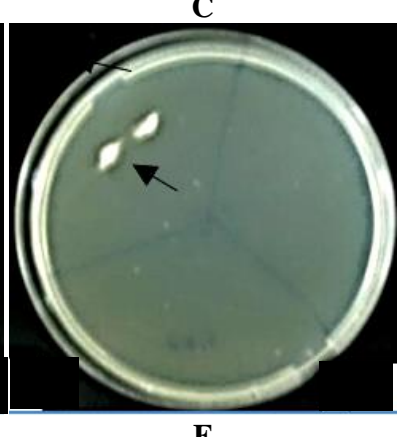

Figure 3. The morphological colonies of Cupriavidus pauculus $\mathrm{IrC} 4$ in medium containing various concentrations of cadmium. A. $0.5 \mathrm{mM}$, B. $1 \mathrm{mM}$; C. $1.5 \mathrm{mM}$; D. $2 \mathrm{mM}$; E. 2.5mM; F. $3 \mathrm{mM}$; G. $4 \mathrm{mM}$ dan H. $5 \mathrm{mM}$. Arrows show the appearance of slime in the colony.

\section{Bacterial growth on broth medium supplemented with copper}

Figure 4 showed that the growth of $C$. pauculus $\mathrm{IrC} 4$ was inhibited when the liquid growth medium was supplemented with $5 \mathrm{mM}$ copper. The bacteria have a lag phase for six hours when the growth medium was supplemented with $7 \mathrm{mM}$ copper and no bacterial growth on a medium containing $9 \mathrm{mM}$ copper (Figure 4). This indicated that the increased copper concentrations were toxic to bacteria. The suboptimal bacterial growth was caused by copper toxicity due to the copper concentration $\geq 5 \mathrm{mM}$, although at lower concentrations copper is a microelement that is needed by bacteria for the metabolic process. Exposure to copper at a concentration exceeding the optimum is toxic and inhibits bacterial growth. (Mazalan et al. 2020).

Perez et al. (2015) reported that some heavy metals at low concentrations are important for the growth and development of microorganisms, but other heavy metals are toxic even in low concentrations. Copper, zinc, and iron are essential heavy metals needed as microelements and cofactors of several enzymes and redox processes. Meanwhile, cadmium, mercury, and lead are non-essential heavy metals that are not involved in important bacteria metabolism. Exposure to these heavy metals is toxic to bacteria and causes denaturation of cell membrane proteins and inhibition of both cell division and cell activity due to nucleic acid damage and transcription process inhibition (Salam et al. 2019).

\section{Bacterial growth on broth medium supplemented with cadmium, lead, and mercury}

Figure 5. shows that bacterial growth was inhibited by the addition of $7 \mathrm{mM}$ and $13 \mathrm{mM}$ of lead. Bacteria did not show a prolonged lag phase, but their growth was not as optimal as bacteria that grew on a medium without the addition of lead. Bacterial growth was also inhibited in the presence of $0.5 \mathrm{mM}$ cadmium, $2 \mathrm{mM}$ mercury, and $0.5 \mathrm{mM}$ as the mixture of copper, lead, and cadmium which had the same inhibitory effect.

This result was supported by the result of Vicentin et al. (2018) that there were differences between bacterial growth in medium containing copper, cadmium, mercury, and lead compared to bacterial growth in medium without heavy metals. A high concentration of heavy metals inhibited the growth of bacteria. Umamaheshwari et al. (2015) reported that cadmium does not play a role in bacterial metabolism, however, it was toxic at low concentrations so that it affected growth, colony morphology, metabolic activity, and decreased bacterial biomass of Bacillus subtilis MTCC-1427. The presence of cadmium inhibited bacterial growth because cadmium damages the active site of the enzyme (Essa et al. 2017). The growth of $C$. metallidurans MSR33 was inhibited in the presence of mercury and recovered after 5 hours, and the addition of mercury in the exponential phase caused bacterial death (Rojas et al. 2015). Mercury inhibits and inactivates metabolic activity because it has a high affinity for the thioester and sulfhydryl groups of proteins (Silva et al. 2018).

This study showed that $C$. pauculus $\mathrm{IrC} 4$ could grow on medium containing essential heavy metals such as copper, as well as non-essential heavy metals such as lead, cadmium, and mercury. It indicated that $C$. pauculus $\mathrm{IrC} 4$ was able to regulate essential and non-essential heavy metal homeostasis so that the presence of these heavy metals did not cause bacterial death. C. pauculus IrC4 could regulate the concentration of copper that enters the cells as a microelement and rejected heavy metals in 
noxious concentrations. Monsieurs et al. (2012) stated that metal homeostasis was important for all bacteria because they had to react quickly to the deficiency and excess of essential and non-essential heavy metals. Bacteria must be able to regulate the concentration of essential intracellular micronutrients within a physiologically acceptable range for cells to function normally. On the other hand, excessive concentrations of toxic essential or non-essential metals can lead to biochemical deficiency. Bacteria have a defensive mechanism against heavy metal toxicity by performing various resistance mechanisms depending on the type of metal and bacterial species such as exhaust pumps, proteins that alter metal oxidation states, and intraor extracellular metal-binding.

\section{Heavy metals accumulation}

The results indicated that the $C$. pauculus $\mathrm{IrC} 4$ performed a resistance mechanism by binding copper and cadmium in cells. The accumulation ability of bacteria in the medium containing $5 \mathrm{mM}$ and $7 \mathrm{mM}$ of copper was almost the same, i.e., $225.32 \mathrm{mg}$ and $237 \mathrm{mg}$ per gram of dry weight of cells, respectively, while the accumulation ability of copper increased to $371.42 \mathrm{mg}$ in a medium containing $9 \mathrm{mM}$ and decreased to $242.13 \mathrm{mg}$ at the concentration of $11 \mathrm{mM}$ (Figure 6). The ability of $C$. pauculus $\mathrm{IrC} 4$ to accumulate lead was lower than its ability to accumulate copper, which was a maximum of $254.44 \mathrm{mg}$ in a medium containing $7 \mathrm{mM}$ of lead. The ability to accumulate lead decreased when the lead concentration was increased to $10 \mathrm{mM}$, which was $147.44 \mathrm{mg}$ copper per gram dry weight of cells (Figure 7). A study by Jaafar et al. (2015) showed that the accumulation of copper, lead, and chromium was initially increased in B. cereus, Bacillus sp. ATS-1, and Pantoea sp. TEM18, however, with the increasing time it was decreased caused by the saturation of the binding sites of heavy metals in bacteria.

The maximum ability of $C$. pauculus $\mathrm{IrC} 4$ to accumulate copper and lead was $371.42 \mathrm{mg}$ and $254.44 \mathrm{mg}$ per gram of dry weight of cells respectively that was higher than that of C. taiwanensis TJ2018. C. taiwanensis TJ2018 has the maximum accumulation of copper and lead of 19.0 $\mathrm{mg}$ and $50.1 \mathrm{mg}$, respectively. The ability to accumulate copper and lead reaches a maximum at a certain concentration and after that, the accumulation ability decreased. It indicated the saturation of the binding site of the heavy metal on the bacterial cell wall. The reduction in the ability to accumulate copper and lead at higher concentrations might be due to the restriction of heavy metals entering the cell to avoid toxicity by extracellular binding by exopolysaccharides or by efflux mechanism. Chatterjee et al. (2012) reported that the lead resistance mechanisms used by lead resistant bacteria included intracellular lead bioaccumulation, efflux mechanisms, and extracellular sequestration.

Cupriavidus pauculus IrC4 grown on the medium added with $0.5 \mathrm{mM}$ cadmium was able to accumulate cadmium of $5.84 \mathrm{mg}$ per gram dry weight of cell. The ability to accumulate cadmium in $C$. pauculus $\mathrm{IrC} 4$ was smaller than that of $C$. taiwanensis TJ2018 with the amount of $19.6 \mathrm{mg}$ (Chen et al. 2008) but higher than that of
Thiobacillus ferroxidans with the amount of $0.31 \mathrm{mg} / \mathrm{g}$ dry weight of cell (Baillet et al. 1997). Due to cadmium redundance, the bacteria developed a different resistance mechanism by secreting EPS to bind copper outside the cell, followed by pumping cadmium out of the cells. Sarma and Chellaiah (2013) reported that some bacteria adapted to a polluted environment could perform several resistance mechanisms such as intracellular and extracellular sequestration, efflux pumps, and bioaccumulation. Cadmium resistance mechanisms by bacteria were performed through the efflux mechanism and the binding of cadmium to EPS (Chellaiah 2018).

Our findings were similar to the previous research that showed the ability of Pseudomonas sp. EJ01 can tolerate 2 $\mathrm{mM} \mathrm{Cd}$ in the media by producing exopolysaccharides. Cadmium resistance in $P$. aeruginosa strains was achieved through the efflux mechanism and the binding of $\mathrm{Cd}$ to the EPS matrix (Chellaiah (2018). EPS is a bacterial metabolic product that serves as a barrier to protect cells against the harsh external environment and plays an important role in the sequestration and biosorption of metal ions required for bacterial metabolism (Bestawy et al. 2013). Mijnendonckx et al. (2010) reported that the ability of $C$. metallidurans $\mathrm{CH} 34$ to carry out efflux pumping enabled it to survive in a medium containing a high concentration of cadmium.

The level of heavy metals accumulation could be used as an indicator of the contamination level in the environment at the site where bacteria was collected. The same genus of bacteria may have different accumulation abilities due to the different levels of pollution where bacteria are collected. . It results in different levels of accumulation ability (Manasi and Rajesh 2016). Bacterial populations isolated from areas contaminated with high concentrations of heavy metals had better resistance than those with low concentrations of heavy metals. C. pauculus $\mathrm{IrC} 4$ is a multiresistant bacteria from the activated sludge waste treatment center in Surabaya so that this strain is accustomed to adapting to polluted environments by developing accumulation resistance mechanisms (Irawati et al. 2012).

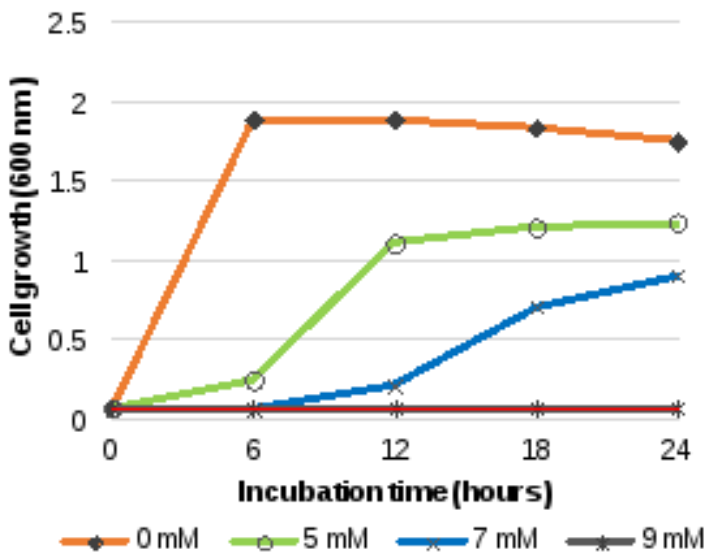

Figure 4. The growth pattern of Cupriavidus pauculus $\mathrm{IrC} 4$ in a medium containing various concentrations of copper 


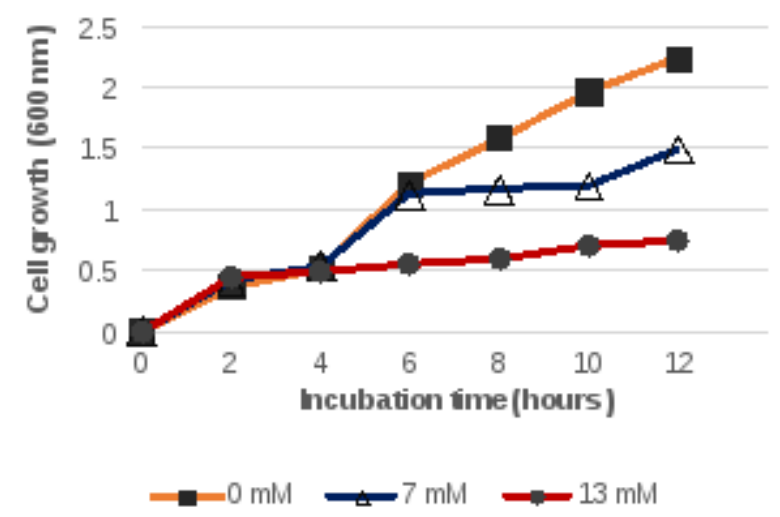

A

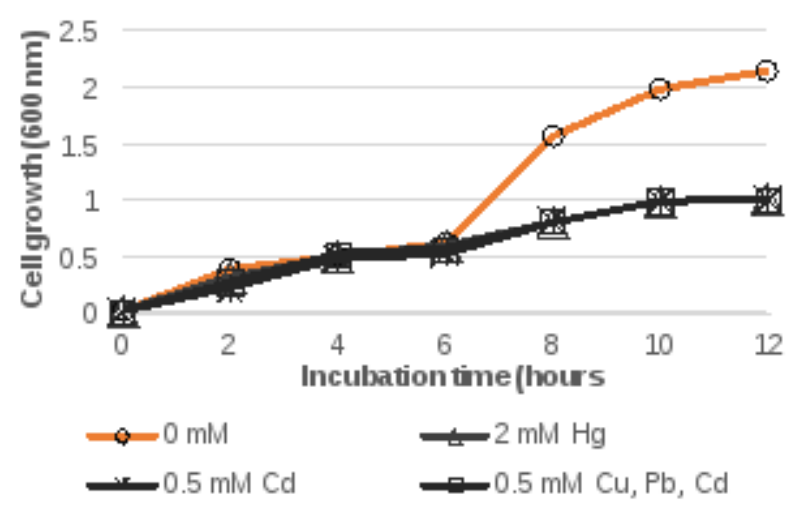

B

Figure 5. The growth pattern of Cupriavidus pauculus $\mathrm{IrC} 4$ in medium containing various concentrations of heavy metals: A. Lead, B. Cadmium, mercury, the mixture of copper, lead, and cadmium

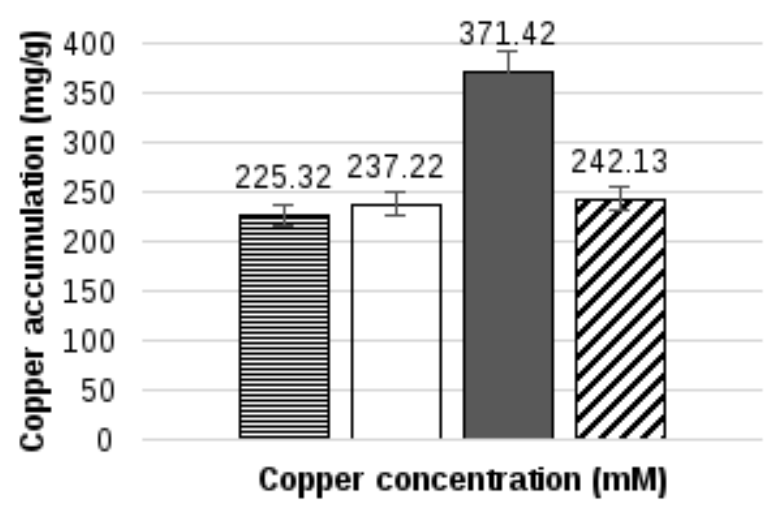

目 $5 \mathrm{mM}$ 口 $7 \mathrm{mM}$ 口9 $\mathrm{mM} \quad 211 \mathrm{mM}$

Figure 6. The level of copper accumulation in Cupriavidus pauculus $\mathrm{IrC} 4$ in a medium containing various concentrations of copper

In conclusion, Cupriavidus pauculus $\mathrm{IrC} 4$ could grow on a solid medium containing $5 \mathrm{mM}$ cadmium, $13 \mathrm{mM}$ lead, and $4 \mathrm{mM}$ mercury. This bacteria strain also could grow on a mixture of heavy metals (cadmium, lead, mercury, and copper). Bacterial growth in the liquid medium was inhibited by the presence of $2 \mathrm{mM}$ mercury, $0.5 \mathrm{mM}$ cadmium, and a mixture of $0.5 \mathrm{mM}$ mercury, cadmium, and copper. In addition, the heavy metals caused the bacteria to produce EPS. Meanwhile, the addition of copper caused changes in the color of the colony to green as a sign of copper accumulation and the edge of the colony to become undulate as a manifestation of copper toxicity and resistance mechanisms. This bacteria strain can accumulate cadmium, lead, and copper respectively by 5.8 $\mathrm{mg}, 254.4 \mathrm{mg}, 371.42 \mathrm{mg}$ per gram of cell dry weight. Based on these results, further studies should be done to determine the potency of $C$. pauculus $\mathrm{IrC} 4$ as a bioremediation agent in wastewater samples containing the mixture of heavy metals, and to evaluate its effectiveness among several pollutants.

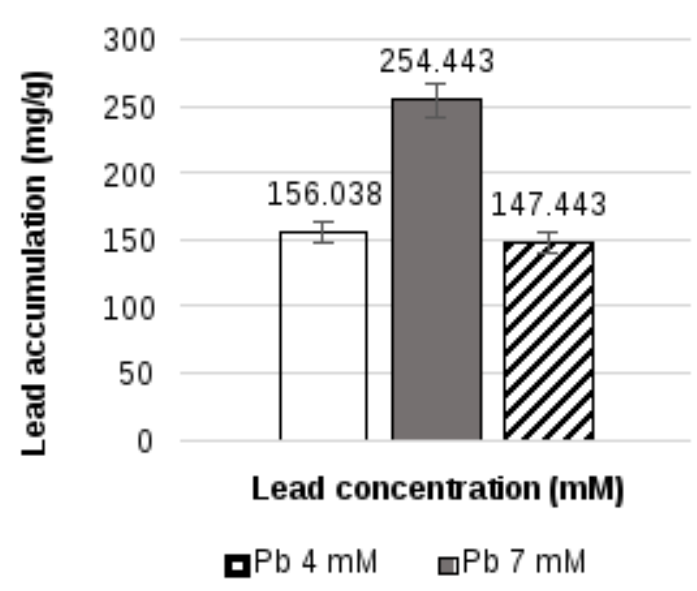

Figure 7. The level of lead accumulation in Cupriavidus pauculus $\mathrm{IrC} 4$ in a medium containing various concentrations of lead

\section{ACKNOWLEDGEMENTS}

The authors thank the Laboratory of Biology of the Faculty of Science and Technology, Pelita Harapan University, Indonesia for funding support. We would also like to thank Fernando Christofer and Greisnaningsi, students of the Department of Biology Education, College of Teachers, Pelita Harapan University for their technical support.

\section{REFERENCES}

Abatenh E, Gizaw B, Tsegaye Z, Wassie M. 2017. The role of microorganisms in bioremediation- a review. Open J Environ Biol 2: 38-46. DOI: 10.17352/ojeb.000007.

Afzal AM, Rasool MH, Waseem M, Aslam B. 2017. Assessment of heavy metal tolerance and biosorptive potential of Klebsiella variicola isolated from industrial effluents. AMB Exp 7: 1-9. DOI: 10.1186/s13568-017-0482-2. 
Arashiro SM. 2018. Lead absorption mechanisms in bacteria as strategies for lead bioremediation. Appl Microbiol Biotechnol 102: 5437-5444. DOI: 10.1007/s00253-018-8969-6.

Baillet F, Magnin JP, Cheruy A, Ozil P. 1997. Cadmium tolerance and uptake by a Thiobacillus ferrooxidans biomass. Environ Technol 18 : 631-638. DOI: 10.1080/09593331808616581.

Bestawy EE, Helmy S, Hussien H, Fahmy M, Amer R. 2013. Bioremediation of heavy metal-contaminated effluent using optimized activated sludge bacteria. Appl Water Sci 3: 181-192. DOI: 10.1007/s13201-012-0071-0.

Cha JS, Cooksey DA. 1991. Copper resistance in Pseudomonas syringae mediated by periplasmic and outer membrane proteins. Proc Natl Acad Sci USA 88: 8915-8919. DOI: 10.1073/pnas.88.20.8915.

Chatterjee M, Canario J, Sarkar SK, Brancho A, Bhattachary K, Saha S 2009. Mercury enrichments in core sediments in Sunderban mangroves, northeastern part of Bay of Bengal and their ecotoxicological significance. Environ Geol 57: 1125-1134. DOI 10.1007/s00254-008-1404-Z

Chellaiah ER. 2018. Cadmium (heavy metals) bioremediation by Pseudomonas aeruginosa: a minireview. Appl Water Sci 8: 154. DOI 10.1007/s13201-018-0796-5.

Chen WM, Wu CH, James EK, Chang JS. 2008. Metal biosorption capability of Cupriavidus taiwanensis and its effect on heavy meta removal by nodulated Mimosa pudica. J Hazard Mater 151: 364-371. DOI: 10.1016/j.jhazmat.2007.05.082.

Chien CC, Lin BC, Wu CH. 2013. Biofilm formation and heavy metal resistance by an environmental Pseudomonas sp. Biochem Eng J 78: 132-137. DOI: 10.1016/j.bej.2013.01.014

Das S, Dash HR, Chakraborty J. 2016. Genetic basis and importance of metal resistant genes in bacteria for bioremediation of contaminated environments with toxic metal pollutants. Appl Microbiol Biotechnol 100: 2967-2984. DOI: 10.1007/s00253-016-7364-4.

Diep P, Mahadevan R, Yakunin AF. 2018. Heavy metal removal by bioaccumulation using genetically engineered microorganisms. Front Bioeng Biotechnol 6: 1-20. DOI: 10.3389/fbioe.2018.00157.

Essa AM, Abbound AM, Khatib SI. 2017. Metal transformation as a strategy for bacterial detoxification of heavy metals. J Basic Microbiol 58: 17-29. DOI: 10.1002/jobm.201700143.

Santos PE, Solano-Rodríguez R, Matsumura-Paz, LT, Vásquez-Murrieta MS. 2014. Cupriavidus plantarum sp. nov., a plant-associated species. Arch Microbiol 196: 811-817. DOI: 10.1007/s00203-014-1018-7

Gonzalez AG, Shirokova SM, Pokrovsky OS, Emnova EE, Martinez RE 2010. Adsorption of copper on Pseudomonas aerofaciens: Protective role of surface exopolysaccharides. J Colloid Interface Sci 350: $305-$ 314. DOI: $10.1016 /$ j.jcis.2010.06.020.

Irawati W, Yuwono T, Hartiko H, Soedarsono J. 2012. Molecular and physiological characterization of copper-resistant bacteria isolated from activated sludge in an industrial wastewater treatment plant in Rungkut. Microbiol Indones 6: 107-116. DOI: 10.5454/mi.6.3.3.

Irawati W, Yuwono T, Soedarsono J, Hartiko H. 2015. The potency of copper_Resistant bacteria Cupriavidus sp. IrC4 isolated from industrial wastewater treatment plant in Rungkut_Surabaya as a bioremediation agent for heavy metals. KnE Life Sci 2: 375-381. DOI: $10.18502 / \mathrm{kls} . v 2 \mathrm{i} 1.179$.

Irawati W, Yuwono T, Rusli A. 2016. Detection of plasmids and curing analysis in copper resistant bacteria. Biodiversitas 17: 296-300.

Irawati W. 2020. Amplification of copper-resistance gene in bacteria isolated from an industrial Sewage in Surabaya. Jurnal Teknologi Lingkungan 21: 16-22. DOI: 10.29122/jtl.v21i1.3274 [Indonesian]

Jaafar R, Al-Sulami A, Al-Taee A, Aldoghachi F, Napes. 2015. Biosorption and bioaccumulation of some heavy metals by Deinococcus Radiodurans isolated from soil in Basra GovernorateIraq. J Biotechnol Biomater 5: 2. DOI: 10.4172/2155-952X.1000190.

Klonowska A, Chaintreuil C, Tisseyre P, Miché L, Melkonian R. 2012. Biodiversity of Mimosa pudica rhizobial symbionts (Cupriavidu taiwanensis, Rhizobium mesoamericanum) in New Caledonia and their adaptation to heavy metal-rich soils. FEMS Microbiol Ecol 81: 618-635. DOI: 10.1111/j.1574-6941.2012.01393.x.
Kunito T, Nagaoka K, Tada N, Saeki K, Senoo K, Oyaizu H, Matsumoto S. 1997. Characterization of Cu-resistant bacterial communities in $\mathrm{Cu}$ contaminated soils. Soil Sci Plant Nutr 43: 709-717. DOI: 10.1080/00380768.1997.10414795.

Manasi NR, Rajesh V. 2016. Evaluation of the genetic basis of heavy metal resistance in an isolate from electronic industry effluent. $\mathrm{J}$ Genet Eng Biotechnol 14: 177-180. DOI: 10.1016/j.jgeb.2016.02.002.

Mazalan NZ, Oyeleye A, Rahman RA, Aris AZ, Salleh AB, Normi YM. 2020. Isolation and characterization of an acid and metal-tolerant Enterobacter cloacae NZS Strain from former mining lake in Selangor, Malaysia. Beni-Suef Univ J Basic Appl Sci 9: 1-12. DOI: 10.1186/s43088-020-00051-1

Mijnendonckx K, Provoost A, Monsieurs P, Leys N, Mergeay M, Mahillon J, Van Houdt R. 2010. Insertion sequence elements in Cupriavidus metallidurans $\mathrm{CH} 34$ : 3 distribution and role in adaptation. Plasmid 65: 193-203. DOI: 10.1016/j.plasmid.2010.12.006.

Monsieurs P, Moors H, Van Houdt R, Janssen PJ, Janssen A, Coninx I, Mergeay M, Leys N. 2011. Heavy metal resistance in Cupriavidus metallidurans $\mathrm{CH} 34$ is governed by an intricate transcriptional network. Biometals 24: 1133-1151. DOI: 10.1007/s10534-011-9473$\mathrm{y}$.

Mutiat FB, Gbolahan B, Olu A. 2018. A comparative study of the wild and mutated heavy metal resistant Klebsiella variicola generated for cadmium bioremediation. Bioremediation $\mathrm{J}$ 22: 28-42. DOI: 10.1080/10889868.2018.1445695.

Perez L, Martinez A, Salgado I, Valdez LA, Cruz S, Allende S, Collazo O, Liva M, Carballo ME. 2020. Zinc and cadmium removal by bacteria: Study of factors associated to the process. Tecnol y Cienc del Agua 11: 309-341. DOI: 10.24850/j-tyca-2020-03-09.

Pradeepa R, Kavitha KK. 2020. Isolation and identification of heavy metal resistant bacteria from an e-waste contaminated soil sites. Intl J Anal Exp Modal Anal 12: 2259-2265.

Rojas LA, Yanez C, Lobos S, Smalla K, Seeger M. 2011. Characterization of the metabolically modified heavy metal-resistant Cupriavidus metallidurans Strain MSR33 generated for mercury bioremediation. PLoS One 6: 1-10. DOI: 10.1186/s42269-019-0208-5.

Salam L, Shomope H, Bukar F. 2019. Mercury contamination imposes structural shift on the microbial community of an agricultural soil. Bull Natl Res Cent 43: 1-13. DOI: 10.1186/s42269-019-0208-5.

Saranraj P, Stella D. 2012. Bioremediation of sugar mill effluent by immobilized bacterial consortium. Int J Res Pure Appl Microbiol 2: 43-48.

Sarma B, Acharya C, Joshi SR. 2013. Characterization of metal tolerant Serratia spp. isolates from sediments of uranium ore deposit of domiasiat in Northeast India. Proc Natl Acad Sci India Sect B Biol Sci 86: 253-260. DOI: 10.1007/s40011-013-0236-0.

Silva FM, Duran N, Seeger M. 2018. Synthesis of extracellular gold nanoparticles using Cupriavidus metallidurans $\mathrm{CH} 34$ cells. IET Nanobiotechnol 12: 40-46. DOI: 10.1049/iet-nbt.2017.0185

Smrithi A, Usha K. 2012. Isolation and characterization of chromium removing bacteria from tannery effluent disposal site. Int $\mathbf{J}$ Adv Biotechnol Res 3: 644-652.

Umamaheshwari K, Poonguzhali P, Sivanandhan S, Khurso A, Ignacimuthu S. 2015. Lead and cadmium resistant bacteria isolated from industrial effluent. J Chem Pharm Res 7: 13-18.

Vicentin RP, Santos JV, Labory CR, Costa AM, Moreira FM, Alves E. 2018. Tolerance to and accumulation of cadmium, copper, and zinc by Cupriavidus necator. Rev Bras Ciens Solo 42: 1-12. DOI: 10.1590/18069657rbcs20170080.

WHO. 2010. Guideline for drinking water quality recommendations. World Health Organization, Geneva.

Wuertz S, Mergeay M. 1997. The impact of heavy metals on soil microbial communities and their activities. In: van Elsas JD, Trevors JT, Wellington EMH (eds) Modern Soil Microbiology. Marcel Dekker, New York.

Wang Y, Robison T, Wiatrowski H. 2013. The impact of ionic mercury on antioxidant defenses in two mercury-sensitive anaerobic bacteria. Biometals 26: 1023-1031. DOI: 10.1007/s10534-013-9679-2. 